\title{
Performance of eight cultivars of sweet basil grown under Egyptian conditions
}

\author{
Reham M. Sabry, A.A.A. Elsayed, M.E. Khattab and S.S. Ahmed \\ Medicinal and Aromatic Plants Research Dept., National Research Centre, 33 El Buhouth St. (former \\ ElTahrir St. ) Dokki, Giza, Egypt. Postal Code: 12622.
}

Received: 10 Oct. 2019/Accepted 30 Nov. 2019/Publication date: 10 Dec. 2019

\begin{abstract}
Two field experiments were conducted during two successive seasons to evaluate growth, yield and essential oil components of eight cultivars of sweet basil (Ocimum basilicum L.). The cultivars under this study were: Edwina, Emily, Eowyn, Genovese, Martina, Rosie, Dolly, Piccolino. Genovese cultivar produced the most vigorous plants with the highest fresh and dry herb yield but the lowest values of leaves and inflorescences percentage per plant. All cultivars yielded essential oil ranging from $0.15 \%$ to $0.46 \%$. All cultivars showed that the dominant oil constituent was linalool (ranging from $37.25 \%$ to $61.99 \%$ ) followed by 1,8 cineole (ranging from $9,5 \%$ to $23.6 \%$ ), $\alpha$-Bergamotene (2.87 to $14.18 \%$ ), $\mathrm{T}$-cadinol (2.13 to $8.3 \%$ ). Considerable amounts of bornyl acetate $(0.20-1.90 \%)$, $\alpha$-terpineol $(0.42-1.62 \%)$, cubenol $(0.13-1.38 \%)$ and $\gamma$-cadinene $(0.80-1.76)$ were also found. Rosie and Dolly cultivars showed the highest content of linalool (61.99 and (61.83).
\end{abstract}

Keywords: sweet basil, cultivars, yield, oil yield, linalool

\section{Introduction}

Sweet Basil (Ocimun basilicum L.) is an annual plant belonging to the family Lamiaceae. It is a popular culinary herb mainly produced by Spain, Italy, France, Egypt, and Mexico, as well as Canada, Hungary and Germany (El-Kereti et al., 2013).

Sweet basil (Ocimum basilicum L.) has the economic importance and is cultivated and utilized throughout the world. Because of its unique organic compounds and different compositions of essential oil extracted from the leaves and flowering tops, plants are widely used worldwide as a medicinal, aromatic, and spice plant (De Masi et al., 2006).

Basil leaves can be consumed fresh or dry as a condiment in food industries to add aroma and flavor to salads, pizzas, meats and soups. The most important type cultivated in the Mediterranean region is the so-called 'European' or 'sweet' basil, generally characterized by essential oils rich of linalool, 1.8-cineole, eugenol, methyl eugenol, and estragole (methylchavicol) with minor and variable amounts of monoterpene and sesquiterpene hydrocarbons.

Basil traditionally has been used to treat headaches, coughs, diarrhea, constipation, warts, worms as well as kidney malfunction. In addition, fresh leaves and flowers yield an essential oil of distinctive aroma that possesses various beneficial effects, e.g., antiseptic, carminative, antimicrobial, sedative, anticonvulsant, antitumor and antioxidative properties (Zheljazkov et al., 2008).

Sweet basil plants have different medicinal values because of the presence of several bioactive compounds accumulated in leaf and flower secretory tissues. It has insect repellent, antifungal, insecticidal and nematicidal properties (chavan \& Nikam 1982, Deshpande and Tipnis 1997).

Also, essential oil can be used in manufacturing of pharmaceutical preparations, dental products, cosmetics, perfumes and fragrances.

The content and chemical composition of the basil essential oil has been the subject of many studies. The yield from different plant parts varies between $0.2-1.9 \%$ with the main components being linalool, methyl chavicol, eugenol and methyl cinnamate, as well as 1,8-cineole, methyl eugenol, geraniol, geranial, neral and $\alpha$-bergamotene (Lee et al., 2005, Günther \& Althausen, 1949)

According to FAO (2017), Egypt is one of the main exporting countries of basil. Genovese basil (Ocimum basilicum L. var. basilicum) is one of the most important varieties of sweet basil that is well known by its diversity as a source of essential oils (Maggio et al., 2016).

According to marotti et al., (1996) the European chemotype of basil from Italy, France and Egypt is considered to have the finest flavor, which has linalool and methylchavicol as main components.

Corresponding Author: Reham M. Sabry, Medicinal and Aromatic Plants Research Dept., National Research Centre, 33 El Buhouth St. (former ElTahrir St.) Dokki, Giza, Egypt. Postal Code: 12622. E-mail:rehamsabry2000@hotmail.com 
Several studies demonstrated that morphological characteristics and aroma profile of basil varieties are greatly influenced by their geographical origin, genetic factors, cultivar used and the methods of cultivation and harvest adopted (Blank et al., 2007).

Hence, the morphological and chemical variability of the basil creates great possibilities for growing different cultivars of this valuable herbal plant. Numerous basil cultivars and forms, are differed in plant size, habitus, color, shape and size of the leaves and flowers, content and chemical composition of the essential oil, as well as other biologically active substances (Saran et al., 2017).

Therefore, the objective of this study was to evaluate the performance and other agronomic characteristics of eight sweet basil cultivars grown in the open field under Egyptian conditions aiming at obtaining information on these cultivars like their biomass and essential oil yield and composition.

\section{Materials and Methods}

The experiment was conducted during the two consecutive seasons of 2018 and 2019 at the Research Station of the Agriculture Faculty, Cairo University located in Giza, Egypt. The soil is characterized by silt loamy texture with low organic matter content $(0.39 \%)$. The soil contained total $\mathrm{N}(1.12 \%)$, total P $(0.088 \%)$, total $\mathrm{K}(0.20 \%)$, pH. $(7.84)$ and Ec. $(2.35 \mathrm{ds} / \mathrm{m})$.

Enza Zaden (Assem Dos, Egypt) kindly provided us with seeds of eight cultivars from sweet basil (Ocimum basilicum L.) The cultivars studied were: Edwina, Emily, Eowyn, Genovese, Martina, Rosie, Dolly, Piccolino. Seeds are sown in seedbeds in the first week of February during both seasons. In March, 45 day-old seedlings were transplanted to the open field and placing them at rows $60 \mathrm{~cm}$ apart and $25 \mathrm{~cm}$ between plants.

Sweet basil cultivars were randomized within the plots and repeated three times in a randomized complete block design. During the period of plant growth, the fertilization was carried out by applying $150 \mathrm{~kg} /$ fed. superphosphate $\left(15.5 \% \mathrm{P}_{2} \mathrm{O}_{5}\right), 200 \mathrm{~kg} / \mathrm{fed}$ ammonium nitrate $(33.5 \% \mathrm{~N})$ and $100 \mathrm{~kg}$ /fed potassium sulfate $\left(48 \% \mathrm{~K}_{2} \mathrm{O}\right)$. Irrigation and other agricultural practices were carried out as usually recommended for basil production in Egypt.

All the cultivars were harvested twice by hand in full bloom by cutting at $10 \mathrm{~cm}$ aboveground. The dates of harvests were June and August in both seasons. For each harvest, plant height $(\mathrm{cm})$, canopy width $(\mathrm{cm})$, fresh and air-dry weights (g/plant), leaves (g/plant), stems (g/plant) and flowers (g/plant), oil percent (\%), yields of fresh, dry herb and oil ( $\mathrm{kg} / \mathrm{fed}$.) were also estimated.

Samples of air-dried herb of each cultivar at each harvest in both seasons were hydro-distilled for 3 hours using Clevenger-type apparatus to extract and determine essential oil percent according to Egyptian Pharmacopoeia (1984). The resulted essential oil was separately dehydrated over anhydrous sodium sulphate and stored in sealed glass vials at $4^{\circ} \mathrm{C}$ until further analysis.

The essential oil constituents were analyzed in the essential oil samples of the second harvest in the second season. The dehydrated oil of each cultivar was subsequently analyzed using a Gas chromatography-mass spectrometry (GC-MS) to evaluate oil quality.

The GC-MS system (Agilent Technologies) was equipped with gas chromatograph (7890B) and mass spectrometer detector (5977A) at the Central Laboratories Network, National Research Centre, Cairo, Egypt. Samples were diluted with hexane (1:19, v/v). The GC was equipped with HP-5MS column ( $30 \mathrm{~m} \times 0.25 \mathrm{~mm}$ internal diameter and $0.25 \mu \mathrm{m}$ film thickness). Analyses were carried out using helium as the carrier gas at a flow rate of $1.0 \mathrm{ml} / \mathrm{min}$ at a split ratio of $1: 1$, injection volume of 1 $\mu \mathrm{l}$ and the following temperature program: $40^{\circ} \mathrm{C}$ for $1 \mathrm{~min}$; rising at $4{ }^{\circ} \mathrm{C} / \mathrm{min}$ to $150{ }^{\circ} \mathrm{C}$ and held for $6 \mathrm{~min}$; rising at $4{ }^{\circ} \mathrm{C} / \mathrm{min}$ to $210^{\circ} \mathrm{C}$ and held for $1 \mathrm{~min}$. The injector and detector were held at $280^{\circ} \mathrm{C}$ and $220{ }^{\circ} \mathrm{C}$, respectively. Mass spectra were obtained by electron ionization (EI) at $70 \mathrm{eV}$; using a spectral range of $\mathrm{m} / \mathrm{z} 40-550$ and solvent delay $5 \mathrm{~min}$. Identification of different constituents was determined by comparing the spectrum fragmentation pattern with those stored in Wiley and NIST Mass Spectral Library data.

Normality distributions in each season were checked out by the Wilk Shapiro test (Neter et al., 1996). An analysis of variance (ANOVA) was done for each season separately according to procedures reported by Gomez and Gomez (1984). Treatments mean were tested according to the Duncan's Multiple Range Test at a probability level of 5\% (Duncan, 1955). 


\section{Results and Discussion}

Growth parameters of eight sweet basil cultivars at the first and the second harvests in both seasons are shown in Table 1. Genovese, Dolly, Edwina, Eowyn and Martina cultivars were different in morphology from Piccolino, Emily and Rosie cultivars since they were taller and had greater canopy width, fresh and dry weights/plant.

Generally, Genovese cultivar presented the highest values for all tested growth parameters compared to other cultivars.

Among the tested cultivars, the tallest plants were observed from Genovese cultivar followed by Eowyn, Dolly and Edwina cultivars meanwhile, the shortest cultivars were Piccolino and Emily.

As for canopy width, it was noticed that Genovese and Dolly cultivars presented greater canopy than the remaining ones especially in the first harvest while in the second one Edwina, Eowyn and Martina cultivars perhaps they became more inclined to branch out and exceeded Dolly cultivar.

Table 1: Means of the variables plant height $(\mathrm{cm})$, canopy width $(\mathrm{cm})$, plant fresh weight $\left(\mathrm{g} \mathrm{plant}^{-1}\right)$, plant dry weight (g plant- ${ }^{1}$ ) of basil cultivars cultivated in two successive seasons (2018 and 2019).

\begin{tabular}{|c|c|c|c|c|c|c|c|c|}
\hline \multirow[b]{2}{*}{ Cultivar } & \multicolumn{2}{|c|}{$\begin{array}{l}\text { Plant height } \\
\left.\text { (cm plant- }^{1}\right)\end{array}$} & \multicolumn{2}{|c|}{$\begin{array}{c}\text { Canopy width } \\
\left.\text { (cm plant- }^{1}\right)\end{array}$} & \multicolumn{2}{|c|}{$\begin{array}{c}\text { fresh weight } \\
\left.\text { (g plant- }^{1}\right)\end{array}$} & \multicolumn{2}{|c|}{$\begin{array}{l}\text { dry weight } \\
\text { (g plant- }^{1} \text { ) }\end{array}$} \\
\hline & $\begin{array}{c}1^{\text {st }} \\
\text { harvest }\end{array}$ & $\begin{array}{c}2^{\text {nd }} \\
\text { harvest }\end{array}$ & $\begin{array}{c}1^{\text {st }} \\
\text { harvest }\end{array}$ & $\begin{array}{c}2^{\text {nd }} \\
\text { harvest }\end{array}$ & $\begin{array}{c}1^{\text {st }} \\
\text { harvest }\end{array}$ & $\begin{array}{c}2^{\text {nd }} \\
\text { harvest }\end{array}$ & $\begin{array}{c}1^{\text {st }} \\
\text { harvest }\end{array}$ & $\begin{array}{c}2^{\text {nd }} \\
\text { harvest }\end{array}$ \\
\hline \multicolumn{9}{|c|}{ First season } \\
\hline Piccolino & $22.20 \mathrm{~g}$ & $21.37 \mathrm{e}$ & $16.93 \mathrm{e}$ & $18.63 \mathrm{e}$ & $128.07 \mathrm{de}$ & $125.80 \mathrm{e}$ & $32.02 \mathrm{~d}$ & $30.20 \mathrm{e}$ \\
\hline Rosie & $36.03 \mathrm{e}$ & $35.13 \mathrm{~d}$ & $25.87 \mathrm{c}$ & $22.27 \mathrm{~d}$ & $113.73 \mathrm{e}$ & $150.83 \mathrm{e}$ & $29.12 \mathrm{~d}$ & $33.90 \mathrm{e}$ \\
\hline Emily & $27.03 \mathrm{f}$ & $33.83 \mathrm{~d}$ & $20.33 \mathrm{~d}$ & $29.53 \mathrm{c}$ & $99.40 \mathrm{e}$ & $126.03 \mathrm{e}$ & $27.83 \mathrm{~d}$ & $35.16 \mathrm{e}$ \\
\hline Martina & $42.67 \mathrm{~d}$ & $43.97 \mathrm{c}$ & $24.17 \mathrm{c}$ & $33.70 \mathrm{~b}$ & $248.23 \mathrm{c}$ & $310.83 \mathrm{~d}$ & $69.50 \mathrm{c}$ & $74.70 \mathrm{~d}$ \\
\hline Eowyn & $47.20 \mathrm{~b}$ & $50.70 \mathrm{~b}$ & $25.33 \mathrm{c}$ & $34.57 \mathrm{ab}$ & $230.87 \mathrm{c}$ & $380.03 \mathrm{~b}$ & $64.64 \mathrm{c}$ & $106.41 \mathrm{~b}$ \\
\hline Edwina & $43.43 \mathrm{~cd}$ & $48.60 \mathrm{bc}$ & $29.23 \mathrm{~b}$ & $34.67 \mathrm{ab}$ & $148.93 \mathrm{~d}$ & $305.13 \mathrm{~d}$ & $34.25 \mathrm{~d}$ & $70.18 \mathrm{~d}$ \\
\hline Genovese & $61.30 \mathrm{a}$ & $57.77 \mathrm{a}$ & $36.30 \mathrm{a}$ & $37.50 \mathrm{a}$ & $439.97 \mathrm{a}$ & $520.33 \mathrm{a}$ & $118.79 \mathrm{a}$ & $114.47 \mathrm{a}$ \\
\hline \multicolumn{9}{|c|}{ Second season } \\
\hline Dolly & $47.70 \mathrm{~b}$ & $46.27 \mathrm{~cd}$ & $37.60 \mathrm{a}$ & $31.33 \mathrm{c}$ & $320.17 \mathrm{~b}$ & $340.63 \mathrm{bc}$ & $86.44 b$ & $79.567 \mathrm{c}$ \\
\hline Emily & $25.63 \mathrm{e}$ & $31.20 \mathrm{e}$ & $25.60 \mathrm{c}$ & $30.90 \mathrm{c}$ & $104.17 \mathrm{f}$ & $122.87 \mathrm{~d}$ & $29.13 \mathrm{de}$ & $34.277 \mathrm{~d}$ \\
\hline Martina & $43.70 \mathrm{c}$ & $45.43 \mathrm{~d}$ & $26.27 \mathrm{bc}$ & $34.23 \mathrm{bc}$ & $236.90 \mathrm{c}$ & $306.37 \mathrm{c}$ & $66.09 \mathrm{c}$ & $75.433 \mathrm{c}$ \\
\hline Eowyn & $48.73 \mathrm{~b}$ & $51.43 \mathrm{~b}$ & $26.00 \mathrm{bc}$ & $35.63 \mathrm{ab}$ & $236.87 \mathrm{c}$ & $371.17 \mathrm{~b}$ & $62.27 \mathrm{c}$ & $99.967 \mathrm{~b}$ \\
\hline Edwina & $42.87 \mathrm{c}$ & $50.53 \mathrm{bc}$ & $30.10 \mathrm{~b}$ & $36.00 \mathrm{ab}$ & $150.27 \mathrm{~d}$ & $323.43 \mathrm{c}$ & $34.56 \mathrm{~d}$ & $74.00 \mathrm{c}$ \\
\hline Genovese & $68.63 \mathrm{a}$ & $59.47 \mathrm{a}$ & $36.10 \mathrm{a}$ & $39.20 \mathrm{a}$ & $423.20 \mathrm{a}$ & $496.43 \mathrm{a}$ & $114.26 \mathrm{a}$ & $109.8 \mathrm{a}$ \\
\hline
\end{tabular}

Sweet basil cultivars had the greatest variability in plant fresh weight ranging from Emily $(99.40 \mathrm{~g})$ to Genovese $(520.33 \mathrm{~g})$. Genovese cultivar presented the highest fresh weight per plant compared to other cultivars. Martina, Eowyn and Edwina cultivars had significantly lower weights when compared with Dolly cultivar in the first harvest but in the second one, a pronounced increment was found in their weights. Also, Piccolino, Rosie and Emily cultivars had lower weights when compared to the other cultivars with no significant differences between them.

Trends in dry weight per plant were similar to that of fresh weight. Genovese cultivar produced the greatest values whereas Emily and Rosie cultivars produced the least in the first harvest as well as Piccolino in the second harvest.

Our measured growth parameters are within the range of values recorded for sweet basil varieties within the literature. For example, Ferrarezi \& Baiely (2019) evaluated seven basil cultivars for tropical outdoor aquaponics production and they noticed that canopy fresh and dry weights were influenced by cultivars. Genovese was the highest yielding cultivar with the highest canopy dry weight and the highest total fresh yield (14.91 kg/m2). Also, Pinto et al., (2018) showed that Genovese and Edwina cultivars presented similar growth parameters in dry season but in the rainy season Genovese cultivar was superior to Edwina in leaf dry weight $(27.7 \mathrm{~g}$ and $26.5 \mathrm{~g}$ ) and oil yield 
(0.22 $\mathrm{ml}$ and $0.21 \mathrm{ml} /$ plant). Maggio et al., (2016) concluded that the values of plant height were generally higher among the selections of Genovese type at the vegetative stage before the beginning of budding.

However, there were some differences in the measurements we recorded from the previous study by Frerichs et al., (2017) who found that Edwina basil presented the highest values of plant height and fresh weight per plant $(23 \mathrm{~cm}$ and $81.7 \mathrm{~g}$ respectively). This may be due to that some characteristics like plant height and plant width of basil plants relies essentially on the environmental conditions, while the shape, surface and edge of the leaf blade are genetically controlled. In addition, production of fresh biomass per plant for Edwina, Emily, Eowyn, Genovese and Martina cultivars were 211, 194, 165, 189 and $118 \mathrm{~g}$, resectively which were lower than those reported in our study (Wierdak \& Borowski, 2011).

There is a statistically significant difference between the tested cultivars in their content of the essential oil, which obviously was higher in the second harvest than in the first one (Table 2). All cultivars tested in the present work yielded essential oil ranging from $0.15 \%$ to $0.46 \%$. The highest oil percentages among the cultivars obtained from Piccolino, Genovese, Rosie and Eowyn while Emily and Martina cultivars gave the least. The essential oil percent was relatively high for Edwina and Dolly cultivars ranging from $0.27 \%$ to 0.37 .

Great variations in the essential oil percent of $O$. basilicum between cultivars were reported by many authors. Our range of oil percent was much lower than that reported by Maggio et al., (2016) who mentioned that the essential oil percentages of Genovese, Martina and Piccolino were $0.61,0.48$ and 1.53 , respectively. However, oil percentages of the cultivars under study were within the range for sweet basil found in other reports.

For example, previous report on 10 tested basil populations found essential oil percentage varied between $0.87 \%$ to $1.84 \%$ (Jelačić et al.,2011).

Table 2: Means of the variables oil percent (\%), fresh yield herb ( $\mathrm{kg} / \mathrm{fed})$, dry herb yield $(\mathrm{kg} / \mathrm{fed})$ and oil yield ( $1 /$ fed) of basil cultivars cultivated in two successive seasons $(2018 / 2019)$.

\begin{tabular}{lcccccccc}
\hline & \multicolumn{2}{c}{$\begin{array}{c}\text { Oil percent } \\
\text { (\%) }\end{array}$} & \multicolumn{2}{c}{$\begin{array}{c}\text { Fresh herb yield } \\
\text { Kg/fed }\end{array}$} & $\begin{array}{c}\text { Dry herb yield } \\
\text { Kg/fed }\end{array}$ & \multicolumn{2}{c}{$\begin{array}{c}\text { Oil yield } \\
\text { 1/fed }\end{array}$} \\
\cline { 2 - 9 } Cultivar & $\begin{array}{c}\mathbf{1}^{\text {st }} \\
\text { harvest }\end{array}$ & $\begin{array}{c}\mathbf{2}^{\text {nd }} \\
\text { harvest }\end{array}$ & $\begin{array}{c}\mathbf{1}^{\text {st }} \\
\text { harvest }\end{array}$ & $\begin{array}{c}\mathbf{2}^{\text {nd }} \\
\text { harvest }\end{array}$ & $\begin{array}{c}\mathbf{1}^{\text {st }} \\
\text { harvest }\end{array}$ & $\begin{array}{c}\mathbf{2}^{\text {nd }} \\
\text { harvest }\end{array}$ & $\begin{array}{c}\mathbf{1}^{\text {st }} \\
\text { harvest }\end{array}$ & $\begin{array}{c}\mathbf{2}^{\text {nd }} \\
\text { harvest }\end{array}$ \\
\hline Piccolino & $0.36 \mathrm{a}$ & $0.44 \mathrm{a}$ & $2817.4 \mathrm{de}$ & $\begin{array}{c}\text { First season } \\
2767.6 \mathrm{e}\end{array}$ & $704.3 \mathrm{~d}$ & $664.4 \mathrm{e}$ & $2.30 \mathrm{c}$ & $2.53 \mathrm{ef}$ \\
Rosie & $0.34 \mathrm{a}$ & $0.38 \mathrm{bc}$ & $2502.1 \mathrm{e}$ & $3318.3 \mathrm{e}$ & $640.5 \mathrm{~d}$ & $745.8 \mathrm{e}$ & $2.18 \mathrm{~cd}$ & $3.28 \mathrm{de}$ \\
Dolly & $0.273 \mathrm{~b}$ & $0.32 \mathrm{~d}$ & $6930.7 \mathrm{~b}$ & $7470.4 \mathrm{c}$ & $1871.3 \mathrm{~b}$ & $1822.3 \mathrm{c}$ & $5.16 \mathrm{~b}$ & $5.84 \mathrm{c}$ \\
Emily & $0.153 \mathrm{c}$ & $0.22 \mathrm{e}$ & $2186.8 \mathrm{e}$ & $2772.7 \mathrm{e}$ & $612.3 \mathrm{~d}$ & $773.5 \mathrm{e}$ & $0.95 \mathrm{~d}$ & $1.70 \mathrm{f}$ \\
Martina & $0.16 \mathrm{c}$ & $0.22 \mathrm{e}$ & $5461.1 \mathrm{c}$ & $6838.3 \mathrm{~d}$ & $1529.0 \mathrm{c}$ & $1643.4 \mathrm{~d}$ & $2.44 \mathrm{c}$ & $3.61 \mathrm{~d}$ \\
Eowyn & $0.34 \mathrm{a}$ & $0.4 \mathrm{ab}$ & $5079.0 \mathrm{c}$ & $8360.7 \mathrm{~b}$ & $1422.1 \mathrm{c}$ & $2341.0 \mathrm{~b}$ & $4.89 \mathrm{~b}$ & $9.36 \mathrm{~b}$ \\
Edwina & $0.28 \mathrm{~b}$ & $0.333 \mathrm{~cd}$ & $3276.5 \mathrm{~d}$ & $6712.9 \mathrm{~d}$ & $753.6 \mathrm{~d}$ & $1543.9 \mathrm{~d}$ & $2.11 \mathrm{~cd}$ & $5.17 \mathrm{c}$ \\
Genovese & $0.32 \mathrm{ab}$ & $0.433 \mathrm{ab}$ & $9679.2 \mathrm{a}$ & $11447.3 \mathrm{a}$ & $2613.4 \mathrm{a}$ & $2518.2 \mathrm{a}$ & $9.49 \mathrm{a}$ & $10.90 \mathrm{a}$ \\
\hline & & & & Second season & & & \\
Piccolino & $0.38 \mathrm{a}$ & $0.46 \mathrm{a}$ & $2934.8 \mathrm{de}$ & $2804.2 \mathrm{~d}$ & $733.7 \mathrm{~d}$ & $425.3 \mathrm{f}$ & $2.59 \mathrm{c}$ & $1.73 \mathrm{e}$ \\
Rosie & $0.33 \mathrm{c}$ & $0.41 \mathrm{~d}$ & $2633.4 \mathrm{ef}$ & $3187.0 \mathrm{~d}$ & $547.0 \mathrm{e}$ & $759.0 \mathrm{e}$ & $1.81 \mathrm{~d}$ & $3.48 \mathrm{~d}$ \\
Dolly & $0.273 \mathrm{e}$ & $0.353 \mathrm{f}$ & $7043.6 \mathrm{~b}$ & $7493.9 \mathrm{bc}$ & $1901.9 \mathrm{~b}$ & $1750.4 \mathrm{c}$ & $5.21 \mathrm{~b}$ & $6.18 \mathrm{c}$ \\
Emily & $0.16 \mathrm{~g}$ & $0.253 \mathrm{~g}$ & $2291.6 \mathrm{f}$ & $2703.0 \mathrm{~d}$ & $640.9 \mathrm{de}$ & $754.1 \mathrm{e}$ & $1.04 \mathrm{e}$ & $1.91 \mathrm{e}$ \\
Martina & $0.18 \mathrm{f}$ & $0.227 \mathrm{~h}$ & $5211.8 \mathrm{c}$ & $6740.0 \mathrm{c}$ & $1454.0 \mathrm{c}$ & $1659.5 \mathrm{~d}$ & $2.62 \mathrm{c}$ & $3.76 \mathrm{~d}$ \\
Eowyn & $0.347 \mathrm{bc}$ & $0.413 \mathrm{c}$ & $5211.0 \mathrm{c}$ & $8165.6 \mathrm{bc}$ & $1369.8 \mathrm{c}$ & $2199.2 \mathrm{~b}$ & $4.75 \mathrm{~b}$ & $9.09 \mathrm{~b}$ \\
Edwina & $0.3 \mathrm{~d}$ & $0.37 \mathrm{e}$ & $3305.8 \mathrm{~d}$ & $7115.5 \mathrm{c}$ & $760.3 \mathrm{~d}$ & $1628.0 \mathrm{~d}$ & $2.28 \mathrm{~cd}$ & $6.03 \mathrm{c}$ \\
Genovese & $0.35 \mathrm{bc}$ & $0.44 \mathrm{~b}$ & $9310.4 \mathrm{a}$ & $10921.5 \mathrm{a}$ & $2513.8 \mathrm{a}$ & $2415.6 \mathrm{a}$ & $9.64 \mathrm{a}$ & $10.80 \mathrm{a}$ \\
\hline
\end{tabular}

Values within each column followed by the same letter not statistically significant at 5 level

The content of the EO obtained from aerial parts of 10 Italian basil cultivars ranging from $0.3 \%$ to $0.8 \%$. A study by Beatovic et al., (2015) revealed that essential oil percent from twelve Ocimum species varied from $0.65 \%$ to $1.90 \%$.

Furthermore, Ilic et al., (2019) isolated essential oils from dry herbs of three basil cultivars grown in Serbia. Two of the tested cultivars belong to sweet basil group while the third one was large leafed 'Genovese' basil. Essential oil percents were $0.65 \%, 0.41 \%$ and $0.62 \%$ respectively. Also, 
Maggio et al., (2016) evaluated 21 cultivars of basil belonging to 'Genovese', 'Napoletano', and 'Purple basil' types. The highest cultivar in essential oil was Genovese italiko (0.07\%) on a fresh weight basis. However, this result is expected because of dried herb express higher oil concentration than fresh herb mass (Garibay et al., 2016), and the determination of oil percent was at vegetative stage, before the beginning of budding.

It seems that variations in essential oil content is highly related to the environmental conditions and agronomic techniques, growth stage that plants are exposed to during growth, which may explain the large differences in the reported values (Labra et al., 2004).

Data within hand in Table 2 indicated that fresh and dry herb $(\mathrm{Kg} / \mathrm{fed})$ as well as oil (l/fed) yields from different evaluated cultivars showed a great variation with highly significant differences in the first and second harvests of both seasons. Genovese cultivar produced the most vigorous plants with fresh herb yield of about $9.5 \mathrm{t} / \mathrm{fed}$ and $11.5 \mathrm{t} /$ fed in the first and second harvests, respectively. Martina and Eowyn cultivars presented a similar fresh herb yield in the first harvest but Eowyn performed best relative to Martina in the second harvest. In contrast, Emily produced the least vigorous plants with yield of about $2.2 \mathrm{t} / \mathrm{fed}$ and $2.7 \mathrm{t} / \mathrm{fed}$ in the first and second harvests, respectively followed by Piccolino and Rosie cultivars.

Data of dry herb yield presented in Table 2 behaved similarly as that fresh herb yield in the same table. Genovese and Dolly cultivars produced high dry herb yield whereas Eowyn and Martina cultivars produced moderate dry herb yield but varied greatly between the first and second harvests. Emily, Rosie and Piccolino cultivars produced the least dry herb yield in both harvests.

Previous results coincide with those obtained by Wei ( 2016) who revealed that Dolly and 'Genovese' had typical sweet basil morphological characteristics and they are particularly good for fresh harvest as well as they had relatively high dry weight yield. Also, Siura et al., (2014) examining four cultivars of albahaca (Ocimum basilicum L.) from an organic production system and reported that Rosie cultivar have the lowest fresh yield $\left(8 \mathrm{ha}^{-1}\right)$ values because of its smaller plant size. It has a great price may be due to its color and the delicate product which make it suitable for gourmet market whereas Piccolino cultivar showed a higher proportion of salable goods after storage.

While Genovese cultivar produced the highest oil yield in both harvests, Dolly and Eowyn cultivars performed best compared to the remaining cultivars but they were still lower than that of Genovese cultivar. The lowest values of oil yield were obtained from Emily cultivar. In addition, Piccolino, Rosie and Martina cultivars gave similar values of oil yield with no significant differences in most cases. Essential oil yields from Eowyn, Edwina and Rosie cultivars turned out to be much higher (about two fold) in the second harvest compared to the first one.

The increase in essential oil yield for the high yielding cultivar is more dependent on the increment of herb biomass rather than the increase in essential oil percentage.

Fresh, dry and oil yields in our study of different cultivars were within those reported in the literature of Sifola \& Barbieri (2006) who recorded values of $0.568 \%, 5.6 \mathrm{~kg} / \mathrm{ha}$ and $25000.4 \mathrm{~kg} / \mathrm{ha}$ for oil percent, oil yield and fresh biomass. Similarly, Blank et al., (2007) reported the average yield of leaves dry weight and inflorescences (16.60 g per plant), the essential oil percent $(1.37 \%)$ and the oil yield (0.29 ml per plant) of Genovese basil. Also, Raimondi et al., (2006) mentioned that Genovese cultivar gave leaf yield of $2 \mathrm{~kg} / \mathrm{m}^{2}$, Meanwhile, Wogiatzi et al., (2011) in her experiment pointed out that the average fresh weight of the Genovese basil studied was $888 \mathrm{~g} / \mathrm{m}^{2}$ and the dry weight was $130 / \mathrm{m}^{2}$ which were much lower than ours but the essential oil yield was higher (2.1\%).

The illustrated results in Fig 1 emphasized that significant differences with respect to leaves and inflorescences percentage per plant between cultivars were recorded. Eowyn and Edwina cultivars showed the highest values in the first harvest while Piccolino and Emily in the second one. The lowest values were registered for Genovese and Dolly cultivars while Martina and Rosie lied in between. These results were found to be in harmony with those of Sifola \& Barbieri (2006) who reported that the leaf-to-stem ratio of Genovese basil was significantly less than those of other cultivars. It had greater leaf number and plant height, but lower leaf-to-stem ratio. 
A

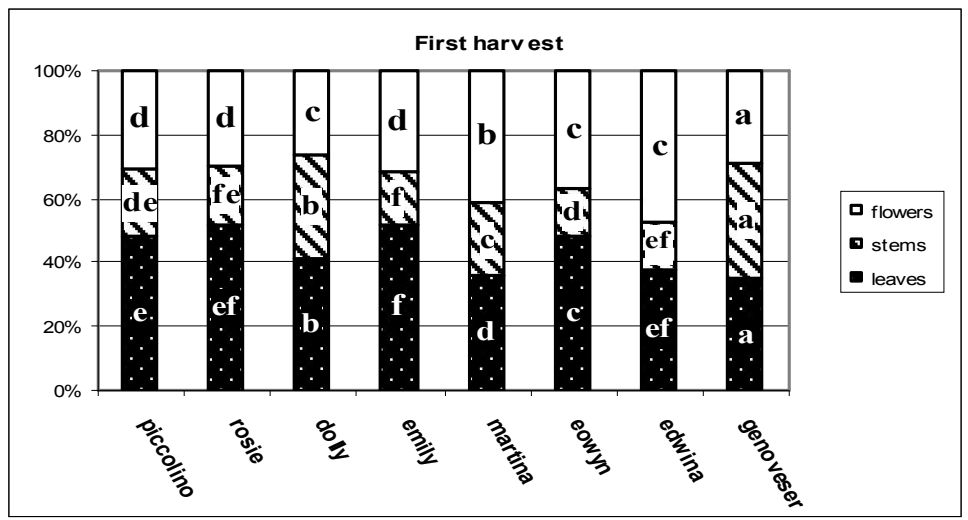

B

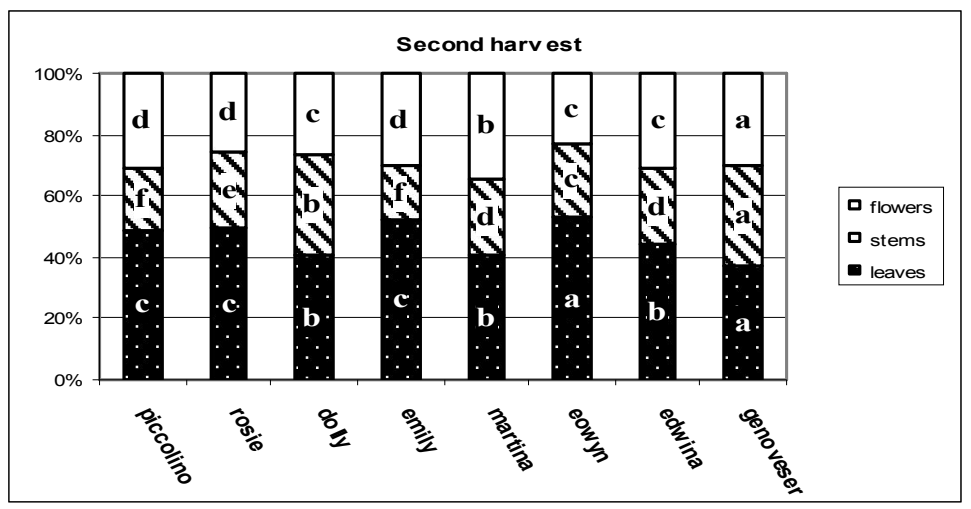

C

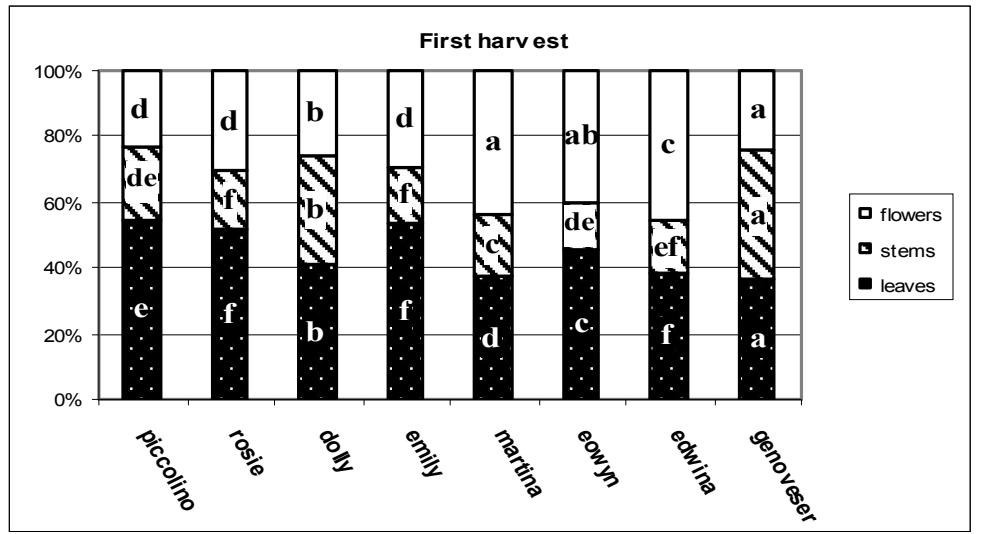

D

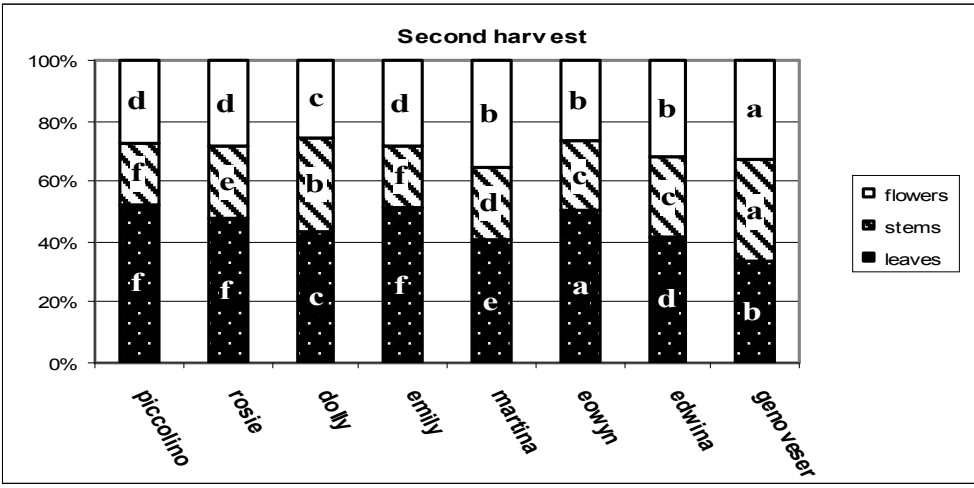

Fig. 1: inflorescences, leaves and stems percentage/plant of different cultivars in the first and second harvests of the first season $(A, B)$ and of the second season $(C, D)$. 
Table 3: Relative abundance (\%) of the main compounds in herb essential oils of sweet basil cultivars (Ocimum basilicum L.) grown in Egypt

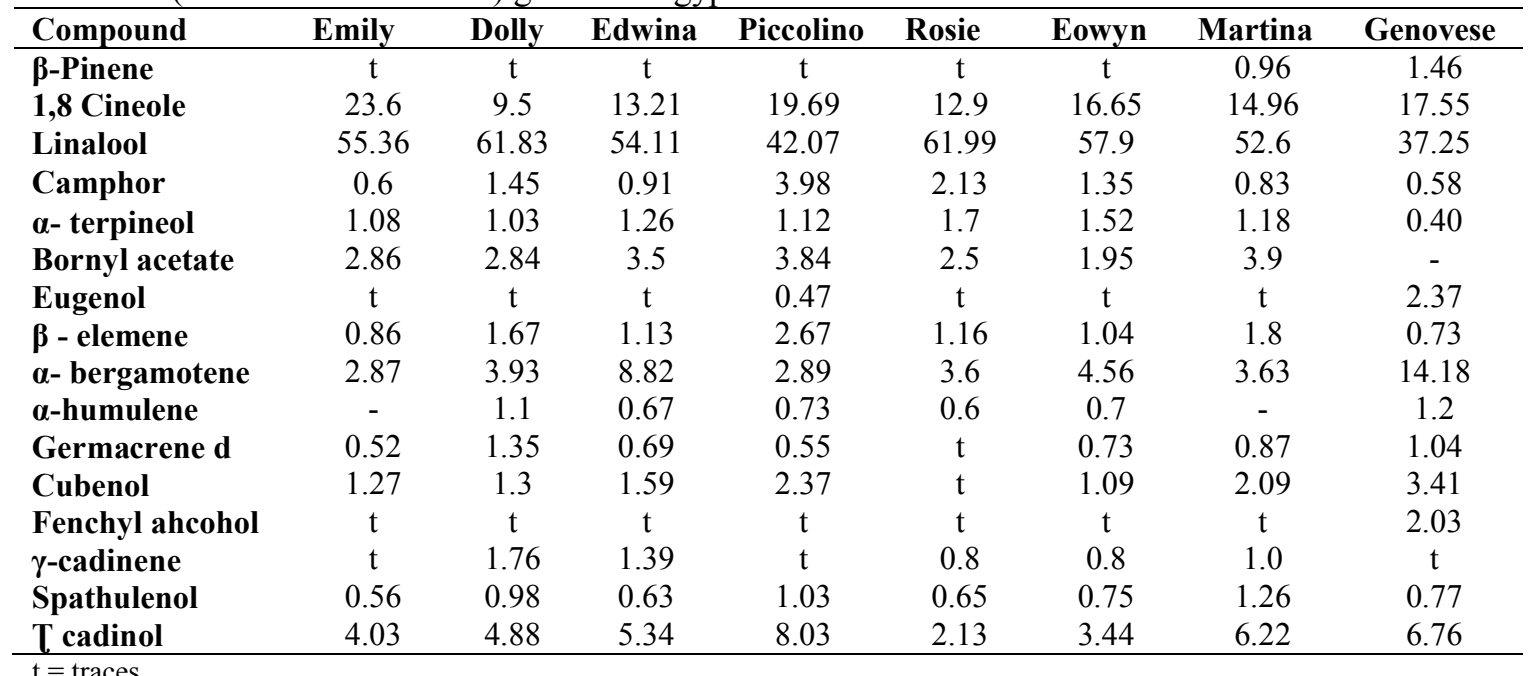

As for essential oil composition of sweet basil (Ocimum basilicum), totally thirty constituents were identified (Table 3). Only the main constituents were listed in Table (3). All cultivars showed that the dominant oil constituent was linalool (ranging from $37.25 \%$ to $61.99 \%$ ). The second major constituent was 1,8 cineole (ranging from 9,5\% to $23.6 \%$ ). $\alpha$-Bergamotene can be considered the third main component in Genovese, Rosie, Eowyn and Edwina cultivars, whereas T -cadinol was the third one in the remained cultivars. Considerable amounts of bornyl acetate $(0.20-1.90 \%), \alpha$-terpineol $(0.42-1.62 \%)$, cubenol $(0.13-1.38 \%)$ and $\gamma$-cadinen $(0.80-1.76)$ were also found.

Considerable variation in relative percentage of essential oil constituents was recorded in the tested cultivars as showed in Table 3 . These differences were observed in the contents of linalool, 1,8 cineole, $\alpha$-bergamotene, $T$ cadinol. Both Rosie and Dolly cultivars had the highest contents of linalool with corresponding decreases in 1.8 cineole contents. Linalool content was high also in Emily and Eowyn cultivars whereas Genovese cultivar had the lowest content of linalool.

On the other hand, Emily cultivar showed the highest content of 1,8 cineole $(23.6 \%)$ whilst Piccolino cultivar had the highest content of $T$ cadinol (8.03\%). In addition, Genovese cultivar contained relatively high concentration of $\alpha$-bergamotene (14.18\%) and also significant amounts of eugenol and fenchyl alcohol which were either not detectable in the other cultivars.

Similar results from previous reports studied the chemical composition of essential oil of Genovese basil and found that linalool was the main constituent (Ilic et al., 2019, Telci et al., 2006, Beatović et al., 2015)

As expected, the essential oil of basil cultivars in our study was somewhat different in composition to the same cultivars in other studies. For example, the essential oil composition of the sweet basil cultivars (Genoveser, Piccolino and Martina) were comparable to another study in Poland by Łożykowska and Król (2008). Linalool and 1,8 cineole in both studies were the main constituents but some constituents in our study such as T cadinol, $\alpha$-bergamotene, bornyl acetate and $\beta$ - elemene were not detected in Poland cultivars. Thus could be due to the differences in the harvesting dates.

In contrast of our results, Maggio et al., (2016) evaluated some cultivars of basil belonging to 'Genovese and revealed that they represented eugenol and methyl eugenol as the most important constituents with low percentage of linalool.

Fortunately, all tested cultivars characterized by a great content of linalool with absence of estragole (have possible carcinogenic and genotoxic effects) which was found in the Egyptian sweet basil (Ocimum basilicum L.) leaves at 14.3\% (Ghenni et al., 2026). In addition, camphor is presented in a small amount and these aforementioned constituents contribute to reduce the quality of basil.

These differences in oil composition from the same cultivars grown in different locations can be explained by a consequence of variations such as growing and environmental conditions, soil characteristics, or production systems, date of harvesting (Ilic et al., 2019). 


\section{Conclusion}

The morphological and chemical variability of the basil creates great possibilities for growing different cultivars of this valuable herbal plant. In this study, Genovese and Dolly cultivars exhibited the highest fresh and dry herb yield. Furthermore, Both Rosie and Dolly cultivars had the highest contents of linalool, which might have special economic value for pharmaceutical and perfume industries or health benefits for humans.

\section{Acknowledgment}

We thank Assem Dos and Co. in the person of Eng. Shrin Abdel Salam Zaki for gifting the basil seeds produced by Enza Zaden Company for this research.

\section{References}

Beatovic, D., D.K. Miloševic, S. Trifunovic, J. Šiljegovic, J. Glamoclija, M. Ristic and S. Jelacic, 2015. Chemical composition, antioxidant and antimicrobial activities of the essential oils of twelve Ocimum basilicum L. cultivars grown in Serbia. Rec. Nat. Prod., 9:1, 62-75.

Blank, A. F., E. M. de Souza, M. F. A. Blank, J. W. A. de Paula and P. B. Alves, 2007. Maria Bonita: a linalool type basil cultivar. Pesq. agropec. bras., Brasília, v.42, n.12, p.1811-1813.

Chavan, S.R., and S.T. Nikam, 1982. Mosquito larvicidal activity of Ocimum basilicum L. Indian, J. Med. Res., 75, 220-222.

Chenni, M., D. El Abed, N. Rakotomanomana, X. Fernandez and F. Chemat, 2016. Comparative Study of Essential Oils Extracted from Egyptian Basil Leaves (Ocimum basilicum L.) Using Hydro-Distillation and Solvent-Free Microwave Extraction. Molecules, 21, 11.

De Masi, L., P. Silviero, C. Esposito, D. Castaldo, F. Siano and B. Laratta, 2006. Assessment of agronomic, chemical and genetic variability in common basil (Ocimum basilicum L.), Eur. Food Res. Technol., 223, 273-281.

Deshpande R.S. and H.P. Tipnis, 1997. Insecticidal activity of Ocimum basilicum L. Pesticides 11, 112.

Duncan, D.B., 1955. Multiple range and multiple F tests. Biometrics, 11 (1): 1-42.

Egyptian Pharmacopoeia, 1984. General Organization for Governmental Printing Affairs, Cairo.

El-Kereti, M. A., S. A. El-feky, M. S. Khater, Y. A. Osman and E. A. El-sherbini, 2013. ZnO Nanofertilizer and He Ne Laser Irradiation for Promoting Growth and Yield of Sweet Basil Plant. Recent Patents on Food, Nutrition \& Agriculture, 5 (3), 169-181.

FAO., 2017. Proposal for new work on codex standard for basil. Codex committee on spices and culinary herbs, $\mathrm{CX} / \mathrm{SCH}, 17 / 03: 1-6$.

Ferrarezi, R. S. and D. S. Bailey, 2019. Basil performance evaluation in aquaponics. Hortechnology, February, 29 (1), 85-93.

Frerichs, C., D. Daum and R. Koch, 2017. Ammonium toxicity - one cause for growth and quality impairments on organic fertilized basil. Journal Fur Kulturpflanzen, 69 (3), 101-112.

Garibay, A. N., B. M. Amador, E. T. Diéguez, J. J. R. Pérez, L. G. H. Montiel and P. Y. Coronado, 2016. Physiological strategies basil cultivars (Ocimum basilicum L.) under protected agriculture. Revista Mexicana de Ciencias Agrícolas Pub. Esp. Núm. 1712 de noviembre - 31 de diciembre, p. 3477-3490.

Gomez, A. K. and A. A. Gomez, 1984. Statistical Procedures for Agricultural Research. John Wiley and Sons. New York, USA.

Günther, E. and D. Althausen, 1949. ß-myrcene. In Günther, E. (ed). The essential oils. The constituents of essential oils. Vol. II. D. Van Nostrand Co., New York, pp. 8-10.

Ilic, A. S., M. P. Antic, S. C. Jelacic and T. M. S. Knudsen, 2019. Chemical composition of the essential oils of three Ocimum basilicum L. cultivars from Serbia. Not Bot Horti Agrobo, 47(2), 347-351.

Jelacic, S.C, D.V. Beatovic, S.A. Prodanovic, S.R. Tasic, Đ.Z. Moravcevic, A.M. Vujoševic and S.M. Vuckovic, 2011. Chemical composition of the essential oil of basil (Ocimum basilicum L. Lamiaceae). Hem. Ind., 65(4): 465-471. 
Labra, M., M. Miele, B. Ledda, F. Grassi, M. Mazzei and F. Sala, 2004. Morphological characterization, essential oil composition and DNA genotyping of Ocimum basilicum L. cultivars. Plant Science, 167, 725-731.

Lee, S. J., K. Umano, T. Shibamoto and K. G. Lee, 2005. Identification of volatile components in basil (Ocimum basilicum L.) and thyme leaves (Thymus vulgaris L.) and their antioxidant properties. Food Chem., 91:131-137.

Łożykowska, K.S. and D. Król, 2008. The content of essential oil in ten sweet basil (Ocimum basilicum L.) cultivars and its composition Herba Polonica, Vol. 54 No 3, 7-12.

Maggio A., G. Roscigno, M. Bruno, E. De Falco and F. Senatore, 2016. Essential oil variability in a collection of Ocimum basilicum L. (basil) ultivars. Chem. Biodiversity, 13, 1357 - 1368.

Marotti M, R. Piccaglia and E. Giovanelli, 1996. Differences in essential oil composition of basil (Ocimum basilicum L.) Italian cultivars related to morphological characteristics. J Agric Food Chem, 44:3926-9.

Neter, J., M. Khutner, C. Nachtsheim and W. Wasserman, 1996. Applied Linear Statistical Models. 4th Ed. Chicago Irwin Series. Time Mirror. Education Group, pp.111-121.

Pinto J. A. O., A. F. Blank, T. M. Andrade, J. C. F. de Sáfilho, L. F. A. Nascimento, D. C. Silva,and M. F. A. Blank, 2018. Cropping season affect the performance of basil cultivars and hybrids. Biosci. J., Uberlândia, v. 34, n. 3, p. 640-647.

Raimondi G., F. Orsini, A. Maggio, S. De Pascale and G. Barbieri, 2006. Yield and quality of hydroponically grown sweet basil cultivars. Proc. I $^{\text {st }}$ IC on Labiatae Eds.: B. Ruffoni et al. Acta Hort. 723, ISHS.

Saran, P.L., H.V. Tripat, R. P. Meena, J. Kumar and R. P. Vasara, 2017. Chemotypic characterization and development of morphological markers in Ocimum basilicum L. germplasm. Scientia Horticulturae, 215:164-171.

Sifola M. I. and G. Barbieri, 2006. Growth, yield and essential oil percent of three cultivars of basil grown under different levels of nitrogen in the field. Scientia Horticulturae 108, 408-413.

Siura, S., X. Reynafarje and F. Avila, 2014. Evaluation of harvest residue incorporation on the organic basil (Ocimum basilicum L.) production in the Mala valley. Anales Científicos, 75 (2): 365-369.

Telci I., E. Bayram, G. Yilmaz and B. Avici, 2006. Variability in essential oil composition of Turkish basils (Ocimum basilicum L.). Biochem. Syst. Ecol., 34, 489-497.

Wei, W., 2016. Winter greenhouse production and tissue culture of basil (Ocimum spp.). A Thesis Presented to the Faculty of The Graduate College at the University of Nebraska, M.Sc., Lincoln, Nebraska.

Wierdak, R. N. and B. Borowski, 2011. Dynamics of sweet basil (Ocimum basilicum L.) Growth affected by cultivar and foliar feeding with nitrogen. Acta Sci. Pol., Hortorum Cultus 10(3), 307-317.

Wogiatzi, E., A. Papachatzis, H. Kalorizou, A. Chouliara and N. Chouliaras, 2011. Evaluation of essential oil yield and chemical components of selected basil cultivars. Biotechnol. \& Biotechnol. Eq. 25/3, 2525-2527.

Zheljazkov, V. D., C. L. Cantrell, W. B. Evans, M. W. Ebelhar and C. Coker, 2008. Yield and composition of Ocimum basilicum L. and Ocimum sanctum L. grown at four locations. Hortscience, 43(3):737-741. 